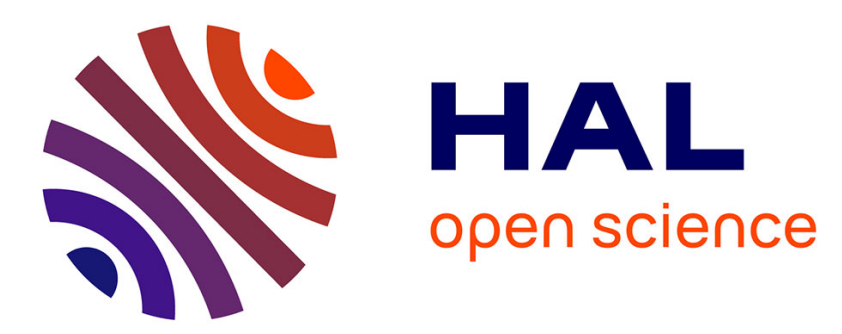

\title{
Biomarkers of atherosclerosis and the potential of MRI for the diagnosis of vulnerable plaque.
}

Emmanuelle Canet-Soulas, Didier Letourneur

\section{To cite this version:}

Emmanuelle Canet-Soulas, Didier Letourneur. Biomarkers of atherosclerosis and the potential of MRI for the diagnosis of vulnerable plaque.. Magnetic Resonance Materials in Physics, Biology and Medicine, 2007, 20 (3), pp.129-42. 10.1007/s10334-007-0078-y . inserm-00162554

\section{HAL Id: inserm-00162554 https://www.hal.inserm.fr/inserm-00162554}

Submitted on 16 Jul 2007

HAL is a multi-disciplinary open access archive for the deposit and dissemination of scientific research documents, whether they are published or not. The documents may come from teaching and research institutions in France or abroad, or from public or private research centers.
L'archive ouverte pluridisciplinaire $\mathbf{H A L}$, est destinée au dépôt et à la diffusion de documents scientifiques de niveau recherche, publiés ou non, émanant des établissements d'enseignement et de recherche français ou étrangers, des laboratoires publics ou privés. 


\title{
Biomarkers of atherosclerosis and the potential of MRI for the diagnosis of vulnerable plaque
}

\author{
E. Canet-Soulas ${ }^{1}$ and D. Letourneur ${ }^{2}$ \\ ${ }^{1}$ Université Lyon 1, Laboratoire CREATIS-LRMN, UMR CNRS 5220, U630 INSERM; \\ ESCPE, 69622 Villeurbanne, France. \\ ${ }^{2}$ INSERM, U 698, Bio-ingénierie Cardiovasculaire, CHU Xavier Bichat, Université Paris 7 , \\ 75018 Paris; Institut Galilée, Université Paris 13, 99 av J.B. Clément, 93430 Villetaneuse, \\ France
}

\section{Correspondence to:}

Emmanuelle Canet-Soulas

Université Lyon 1, ESCPE, Laboratoire CREATIS-LRMN, CNRS UMR 5220, INSERM U630, Domaine Scientifique de la Doua, 43 Bd 11 novembre 1918, 69622 Villeurbanne Cedex, France

Phone: (+33) 472119013

Fax: (+33) 472448199

E-mail: emmanuelle.canet@univ-lyon1.fr 


\begin{abstract}
:
Atherosclerosis is a chronic inflammatory vascular disease. As it is an inflammation process, many cellular and molecular events are involved at each step of the progression of atherosclerosis from an early fatty streak lesion to a highly dangerous rupture-prone plaque. Magnetic Resonance Imaging (MRI) is a well-established diagnostic tool for many kinds of chronic inflammation in various systems and organs, and recent improvements in spatial resolution and contrast strategies make it a promising technique for the characterization of inflammatory vessel walls. The first part of this review will briefly introduce the main cellular and molecular processes involved in atherosclerotic lesions; the second part will focus on the use of high-resolution MRI and present-generation contrast agents for plaque characterization; and the third part will present some recent and ongoing cellular and molecular MRI studies of atherosclerosis.
\end{abstract}




\section{Introduction}

Magnetic Resonance Imaging (MRI) has continuously developed, enhancing image quality and thereby providing more information on the physio-pathological status of biological tissue. The unique advantages of MR for tissue characterization lie in its inherent contrast flexibility, combining different sequences and various contrast media. For atherosclerosis, recent advances in coil and acquisition chain technologies in current clinical scanners have increased spatial resolution, enabling carotid plaque to be imaged with a high signal-to-noise ratio in patients. Carotid plaque is characterized by MRI using multi-contrast acquisition with or without non-specific contrast agent injection. However, for the diagnosis of vulnerable plaque, new contrast agents dedicated to molecular imaging and in vivo biological targeting are required. The question that remains unresolved is the choice of biological target to achieve this goal.

Histopathologically, atherosclerosis is characterized by a progressive accumulation of lipids, cells (smooth muscle cells, macrophages, and T-lymphocytes) and extracellular matrix in the arterial wall. The progression of atherosclerosis from an initial fatty streak to the complex advanced lesion has been described using Stary's six-stage histological classification ${ }^{1}$. It is now established that molecular and cellular inflammatory processes are involved at each step of the pathology ${ }^{2-4}$. The initial events comprise disrupted endothelial homeostasis, characterized by four elements: adhesiveness, permeability, proliferation and thrombogenesis. The initial steps of inflammation are thus clearly described at the interface between blood and vessel wall. The multiple molecular and cellular events explaining subsequent progression are often viewed from the inside of the vessel wall, except for the late event when a clear rupture happens at the wall/blood interface, accompanied by thrombus formation. As these cellular and molecular processes are also found in numerous other human disorders ${ }^{5-8}$, any new diagnostic technology for atherosclerosis would also have a wider impact for the molecular imaging of chronic inflammatory diseases. The increasing number of original articles and reviews demonstrates that atherosclerosis and inflammation are important new challenges for MRI. In the present review, after a short description of the essential biological events, we will focus on the potential diagnostic contribution of MRI and MRI markers at each stage of the atherosclerotic disease and for detecting a vulnerable lesion ahead of rupture. 


\section{Atherosclerosis: the molecular and cellular processes involved in of an inflammatory}

disease

\section{Blood-side events}

Activation of vascular endothelial cells and circulating blood cells together with an increased plasma concentration of inflammatory mediators is characteristic of ongoing inflammatory processes during the progression of atherosclerosis. Some circulating markers of inflammation (e.g., C-reactive protein (CRP), cell adhesion molecules (CAM), monocyte chemoattractant protein (MCP-1), tumor necrosis factor-alpha (TNF $\alpha$ ), interleukins (IL), soluble CD40 ligand (sCD40L), or von Willebrand factor) are currently undergoing clinical trials in patients suffering from cardiovascular diseases ${ }^{5-14}$.

Upon activation, circulating white blood cells express adhesion glycoproteins at their surface (Figure 1). Activated platelets also play a key role as a link between inflammation, thrombosis and atherogenesis ${ }^{15,16}$. Like leukocytes, platelets can roll on the surface of inflamed endothelium. This process is mediated by endothelial P-selectin and a counter-receptor for Pselectin ${ }^{17-19}$. This glycoprotein is part of the GPIb-IX-V complex, which mediates platelet adhesion to exposed sub-endothelial von Willebrand factor at injury sites ${ }^{20}$. Its involvement in platelet adhesion to both activated endothelium and exposed subendothelium makes GPIb $\alpha$, one of the four polypeptides of the complex, an attractive model for the design of mimetic compounds ${ }^{21}$. Activated endothelial cells express CAMs, which favor the recruitment of leukocytes into the arterial wall ${ }^{22}$. The main receptors expressed in the vascular components (Figure 1) are divided into five groups ${ }^{23}$ :

1) Integrins: Integrins are heterodimers of $\alpha \alpha$ subunits and $\alpha \beta$ subunits. The integrin family has subfamilies, designated as $\beta 1$ through $\beta 8$. The most widely studied subfamilies are $\beta 1$ (CD29 or very late activation (VLA) members), $\beta 2$ (leukocyte integrins such as CD11a/CD18, CD11b/CD18, CD11c/CD18, and $\alpha \mathrm{d} \beta 2$ ), $\beta 3$ (CD61 and CD51/CD61 or $\alpha v \beta 3$ integrin or vitronectin receptor), and $\beta 7$ ( $\alpha 4 \beta 7$ and $\alpha E \beta 7)$. A particular integrin may recognize several proteins.

2) Immunoglobulins: The immunoglobulin superfamily includes leukocyte function antigen-2 (LFA-2 or CD2), leukocyte function antigen-3 (LFA-3 or CD58), intercellular adhesion molecules (ICAMs), vascular adhesion molecule-1 (VCAM-1), platelet-endothelial cell adhesion molecule-1 (PECAM-1), and mucosal addressin cell adhesion molecule-1 (MAdCAM-1). The binding sites are different for each of these cell-adhesion molecules. 
3) Cadherins: Cadherins are major cell-cell adhesion molecules. The most extensively studied are N-cadherin, E-cadherin, P-cadherin, and NgCAM. One unique feature of the cadherin family is homophilic binding: i.e., cadherins bind identical cadherins on other cells.

4) Selectins: The selectin family (CD62) includes E-selectin, P-selectin, and Lselectin. Selectins are well-known examples of proteins interacting with saccharide structures. Selectins are type-1 glycoproteins that share common structural determinants. P-selectin (CD62P, PADGEM, GMP-140) and E-selectin (CD62E, ELAM-1) are inducible receptors expressed on activated endothelial cells and/or platelets and binding to glycoconjugates on most leukocytes ${ }^{24}$. L-selectin (CD62L, previously known as MEL-14 antigen or LECAM-1) is constitutively expressed on circulating lymphocytes, neutrophils, monocytes and platelets, and recognizes specific ligands on endothelial cells.

5) Proteoglycans: The proteoglycans encompass a large group of core proteins with attached sulfated glycosaminoglycans (GAG). The specificity of their interactions with vascular components is related to the nature and distribution of the GAG chains 25 .

Thus, arterial wall dysfunction is modulated by interaction between blood elements (circulating leukocytes, platelets, and microparticles derived from platelets or damaged endothelial cells), circulating or local bioactive molecules, cellular and molecular arterial wall components and the lesion's microenvironment (blood flow, wall shear stress, and thrombogenic elements). The goal is then to identify lesions at risk of acute event: i.e., rupture and thrombosis.

\section{Inside the wall inflammation cascade}

Precursor signs of atherogenesis are early phenotypic modulations of intimal smooth muscle cells and cellular activation of the vessel wall by oxidized lipids (oxLDL) and reactive oxygen species (ROS) (Figure 1). Endothelial cells and macrophages are mainly involved in these early processes (Figure 1). For later evolution, pathological examination has demonstrated that plaques with thin ulceration-prone fibrous caps with inflammatory characteristics are responsible for fatal acute thrombosis. This finding has led to the concept of vulnerable lesions, independently of stenosis degree and plaque volume ${ }^{2,26-28}$.

Macrophages and foam cells (lipid-laden macrophages originating from monocytes or from smooth muscle cells) are seen as the central actors in the vicious circle of the establishment 
of atherosclerosis, but many other cells are also involved in the process. Cell recruitment from the blood stream is followed by migration of cells such as $\mathrm{T}$ cells and mast cells from the immune system. In the vessel wall, smooth muscle cells are activated to a proliferating and secretory phenotype (Figure 1). A cascade of signaling and processes such as activation, proliferation, angiogenesis, enzymatic reactions and apoptosis causes evolution to move towards the formation of a complex plaque.

The following events are linked to atherosclerotic plaque evolution:

- activation of an inflammatory process;

- oxidative stress and production of reactive oxygen species (ROS);

- modified phenotypes (activation, proliferation);

- apoptosis;

- angiogenesis;

- thrombogenesis.

These processes involve many cellular and molecular agents. The frequently cited inflammatory mediators or markers (both circulating and tissue-bound) are naturally considered as targets for diagnostic and therapeutic approaches $5,6,14,26,28-32$.

The presence of key players in circulating blood, at the blood/tissue interface or inside the vessel wall is leading to a new concept of vulnerability. Vulnerable plaques are rupture-prone lesions with a prothrombotic microenvironment. A vulnerable patient is a patient at risk of an acute vascular event, presenting a combination of local and systemic risk factors. Clinical biomarkers and molecular imaging of key identified targets will help guide indications and treatment of vulnerable plaque ${ }^{2,5,9,14,28}$. 


\section{MRI techniques for vessel wall imaging: role of contrast agents in plaque characterization}

For any imaging modality, the first step is to visualize the vessel wall in vivo. This is technically challenging as it requires both high spatial resolution and a high signal-to-noise ratio with a minimal acquisition time. Historically, attempts to characterize atherosclerotic plaque components were made ex-vivo, to determine whether the contrast versatility of MRI was helpful. From these initial studies, it was found necessary to associate multiple sequences - i.e., T1, T2, proton density and diffusion weighted sequences - to obtain useful information about plaque composition (Figure 2).

\section{MR characteristics of plaque components}

Recent reviews have described plaque components examined by MRI in experimental and clinical studies. Lipid and necrotic components, fibrous tissue with a dense or loose matrix and extracellular lipids, fibrocellular tissue, calcification with cholesterol crystals, and fresh and old thrombi have been extensively explored ${ }^{32-41}$. Calcification is unequivocally characterized by absence of signal on MR sequences (Figure 2), dense fibrosis by a high signal on T2, lipid-necrotic core by a low signal on T2 and a variable signal on T1, and fresh thrombus by a high signal on T1. Many studies are now focusing on characterizing the fibrous cap - thickness, presence of fissures or inflammation sites, as elements for the assessment of lesion vulnerability or instability. MR contrast agents are very useful here, to delineate the fibrous cap and ulcerations and enhance inflamed tissues ${ }^{42-47}$.

\section{In vivo high-resolution MRI techniques in clinical and experimental settings}

In vivo techniques involve high resolution sequences with the best compromise for temporal resolution. Until recently, spin echo sequences were considered the most useful, despite their relatively long acquisition time.

In humans, most clinical plaque imaging studies have been performed on the carotids. Carotid imaging in patients involves four prerequisites:

- optimized coil for small field of view (carotid coil);

- carefully adjusted coil and patient position, to ensure patient comfort;

- multiple-contrast high-resolution sequences in minimal acquisition time;

- ECG synchronization and bright and black blood acquisitions, with swallowing and respiratory motion under control.

Imaging at 3 Tesla or higher magnetic fields is beneficial in terms of increased signal-to-noise ratio ${ }^{48}$, but limitations such as specific absorption rate (SAR) deposition and optimal coil design still need to be fully explored. 
Experimentally, high resolution is even more crucial in animal models of atherosclerosis such as hypercholesterolemic rabbits or genetically modified mice. In these studies, the main focus of research is seldom plaque component identification but rather physiopathological exploration by molecular targeting and bioengineering, with MRI being used in a multimodal exploration context ${ }^{49}$.

\section{Role of clinically available contrast agents}

Plaque permeability and neovascularization is explored with MRI via conventional nonspecific contrast agents ${ }^{43,46,47,50}$. Either a compromised low-resolution sequence for dynamic acquisition or a single post-contrast time point with a spatial resolution T1 sequence can be used. Non-specific contrast agents diffuse rapidly in the fibrous cap, enabling measurement of thickness and assessment of reactivity ${ }^{42,44-46}$. In MR acquisition using T1 agents, a sufficiently robust $\mathrm{T} 1$ sequence, meeting all the requirements of in vivo acquisition (black blood, ECG synchronization, stable T1 weighting, exclusion of respiratory artifacts, multislice $2 \mathrm{D}$ or $3 \mathrm{D}$ ) remains to be obtained ${ }^{51-53}$. The main studies using gadolinium chelates have dealt with vasa vasorum in the adventitia and angiogenesis. Kinetic models are then applied to evaluate parameters such as blood volume and permeability index ${ }^{46,50}$. The principal limitations of kinetic modeling are those encountered for tumoral angiogenesis measurement: i.e., interstitial diffusion of non-specific contrast agents, and the non-linear relationship between MR signal and contrast agent concentration. The additional difficulty for kinetic studies in the vessel wall is to combine strong and fast T1-weighted MR acquisition, high spatial resolution, a reference blood curve kinetic, and blood and fat signal suppression.

Two main issues are awaiting the arrival on the market of new blood pool agents ${ }^{54}$. First, blood pharmacokinetics is far more appropriate for the study of plaque permeability and neovascularization ${ }^{55}$ (Figure 3 ). Second, the capacity to shorten either tissue T1, T2 or T2* is extended by using macromolecular platforms or nanoparticles ${ }^{28,31,56-58}$. The efficiency of a paramagnetic MR contrast agent is described by its relaxivities $\mathrm{r} 1$ and $\mathrm{r} 2$, which are the constants of proportionality between contrast agent concentration and change in longitudinal or transversal relaxation rate, expressed in $\mathrm{s}^{-1} . \mathrm{mM}^{-1}$ per gadolinium or iron unit. With nonspecific gadolinium contrast agent, $\mathrm{r} 1$ efficiency is rather low $\left(3\right.$ to $\left.5 \mathrm{~s}^{-1} \cdot \mathrm{mM}^{-1}\right)$ at a $1.5 \mathrm{~T}$ clinical magnetic field. Moreover, commercial gadolinium complexes are composed of a single gadolinium entity, whereas blood pool agents may contain several tens of contrast ions. The ratio between $\mathrm{r} 2$ and $\mathrm{r} 1$ determines whether a contrast agent can be better used for contrast-enhanced T1-weighted or T2/T2*-weighted imaging. The gadolinium-based contrast 
agents (see example in Figure 3) are generally employed as T1 agents generating positive contrast (bright spot), as their r2/r1 ratio is low (typically between 1.1 and 2), whereas iron oxide particles are more often viewed as $\mathrm{T} 2 *$ or susceptibility agents with dark spots (Figure 4).

Ultrasmall iron oxide particles (USPIO) have a versatile behavior, depending on their coating and the size of the iron crystal. They are used either as T1 agents for MR angiography applications or as $\mathrm{T} 2 / \mathrm{T} 2 *$ agents for cell labeling purposes ${ }^{31,54,59-62}$. When injected in the blood stream, iron oxide particles encounter phagocytosis by cells of the reticulo-endothelial system. In atherosclerosis, small or ultrasmall iron oxide particles (SPIO or USPIO) have been evaluated both experimentally ${ }^{61-70}$ and clinically ${ }^{71-75}$, as markers of activated monocytes/macrophages, using gradient echo sequences and the T2* effect. Intra-plaque iron particle deposition is visualized as susceptibility-induced signal loss ${ }^{64}$. Contrast changes are related to macrophage iron uptake inside the plaque. However, the intensity of contrast changes depends on many critical factors: i.e., the animal model (genetically modified mice, Watanabe rabbits, or New Zealand rabbits with endothelial denudation and fat diet), and the MRI protocol (USPIO dose and characteristics, MR sequences and imaging window), as discussed in dedicated papers ${ }^{67,76}$.

Studies using iron oxide nanoparticles as markers of activated macrophages in various inflammatory contexts such as stroke or multiple sclerosis have shown that signal loss is a combination of iron particle uptake by macrophages and non-specific diffusion of nanoparticles as a consequence of increased permeability and neovascularization in inflamed tissue ${ }^{77}$. Discriminating T1, T2 and T2* effects is then thought to help the determination of iron location in the extracellular space (T1 effect) and its cellular internalization (T2* effect) ${ }^{61}$. The combination of both should allow follow-up of iron uptake and cell trafficking after iron uptake. Specificity could also be improved by modified coatings or by conjugating the particles with specific ligands (see next section). Thus, ongoing USPIO research aims at improving the specificity and quantification of iron nanoparticles:

$1 /$ by combining T2/T2* and T1 effects on the MR signal using different MR sequences to improve iron location and quantification ${ }^{61,77}$;

2 / by developing MR sequences to generate positive signal from susceptibility effects ${ }^{78,79}$;

3 / by functionalizing USPIO to target the inflammatory process ${ }^{28,49}$;

4/ and by performing direct tracking of iron or fluorescently labeled monocytes by a combination of optical and MR techniques ${ }^{80}$. 


\section{Cellular and molecular targeting of atherosclerosis by MRI markers}

MRI markers can be designed to target either cellular players at the blood/vessel interface or deeper inside the vessel wall, or molecular components identified as key biomarkers (i.e., soluble markers circulating in blood or in the interstitium, or molecules expressed at the surface of activated cells). The main targets and protocols are summarized in Table 1.

In a first approach, non-specific contrast agents or blood pool contrast agents with dynamic contrast enhancement protocols can be used to evaluate inflammatory consequences such as increased permeability and neovascularization ${ }^{45,50,55,81,82}$ (Figure 3).

Cellular MRI in atherosclerosis is mainly represented by monocyte/macrophage imaging. Macrophages were the first targeted cells to be explored by MRI for two reasons: they have a central role in the inflammatory process, and their MR labeling by iron oxide particles is wellknown ${ }^{64,71-73}$. They have been characterized in various experimental animal models (Watanabe rabbit or New Zealand rabbit, fed with a fatty diet after endothelial injury). After iron oxide uptake by macrophages, a susceptibility effect and a focal signal loss is induced, co-located with inflammation on histopathology (Figure 4). Ongoing studies are exploring the influence of the pharmacokinetic behavior and surface coating of the particles (starch, dextran, polyethylene glycol, anionic charges, etc.) on increasing macrophage uptake and MR response specificity, thereby decreasing the non-specific signal from the passive diffusion of iron oxide ${ }^{31,62,66-69}$. The fundamental requirements to go on to large-scale clinical trials with USPIOs are: first, to improve specificity and quantification of iron-induced signal changes in the vessel wall; second, to design standardized protocols on clinical scanners at 1.5 and 3T; and lastly, to document late iron particle biotransformations in inflammatory tissue and their consequences for longitudinal intra-plaque signal intensity monitoring ${ }^{67,76}$.

For molecular imaging, targeting can address the main events of atherosclerosis evolution: i.e., inflammation and angiogenesis, oxidative stress, proliferation and apoptosis and thrombosis (Table 1).

\section{Inflammation and angiogenesis targeting}

The main inflammation targets are cell adhesion molecules (CAM) (Figure 1). MR markers have been designed to target immunoglobulins, such as VCAM-1 ${ }^{49,83}$, the selectin family, such as E selectins ${ }^{84-87}$ and integrins (alpha- $v$ beta-3) ${ }^{88-90}$. As the expression of adhesion 
molecules on activated endothelial cells has been extensively explored in biology and biochemistry, targeting specificity is generally tested on these cells. For VCAM-1, a very small iron oxide particle (CLIO) is used as contrast carrier, combined to a mimetic of VLA4 (Figure 1), the main ligand of VCAM-1. A fluorochrome is added on the iron particles to enable dual optical and MR detection ${ }^{49,83}$. Targeting efficiency was demonstrated by an extensive in vitro study ${ }^{83}$, confirmed in vivo in mice and improved by the phage display technique $^{49,91}$ (Figure 5). For E-selectin, two targeting strategies have been employed, one by adding a monoclonal antibody fragment to the CLIO particles ${ }^{84}$ and the second by grafting a mimetic of the E-selectin ligand onto a gadolinium complex ${ }^{85}$. The specificity of the new markers was evaluated in vitro ${ }^{84,85}$, ex-vivo and in vivo in animal models ${ }^{86,87}$. In addition, a strategy using a mimic of a P-selectin ligand was recently evaluated in mice by our own team to target plaque inflammation ${ }^{92}$.

Alpha- $v$ beta-3 integrin was targeted by addition of the RGD peptide or RGD mimetic on either perfluorocarbon Gd platforms ${ }^{89,90}$ or iron oxide particles ${ }^{93,94}$. The general applications were neovascularization in tumors and angiogenesis ${ }^{94}$, but the strategy was also applied to plaque inflammation diagnosis with the exciting new option of targeted drug delivery ${ }^{88,89}$.

\section{Oxidative stress}

As vessel wall accumulation of lipids triggers oxidative stress, lipophilic or LDL particle markers are of particular interest for plaque imaging. One study investigated specific binding to LDL via the LDL receptor interaction: a lipophilic gadolinium-based agent with an additional fluorophore was synthesized to label LDL particles in vitro and to track labeled LDL in vivo ${ }^{95}$. Other lipophilic gadolinium agents such as gadofluorine ${ }^{96}$ or gadolinium micelles ${ }^{82}$ were applied to plaque imaging in rabbits and mice, and gadolinium liposomes ${ }^{81}$ and functionalized HDL particles ${ }^{97}$ to plaque imaging in mice. Gadolinium micelles have been successfully immunolabeled using the biotin-avidin-biotin bridge technique to target the macrophage scavenger receptor ${ }^{98}$.

Oxidative stress is also under investigation by targeting enzymes such as matrix metalloproteinase ${ }^{99}$ or myeloperoxidase ${ }^{100}$.

\section{Proliferation and apoptosis}

Smooth muscle cell proliferation is involved in the response to vessel wall injury (Figure 1). For proliferation, two options have already been tried on cell cultures, one for molecular imaging only and the second with addition of local drug delivery ${ }^{56,101}$. The target was tissue factor, a transmembrane glycoprotein present at the surface of activated cells. It is responsible 
for the initial phases of thrombosis and is also involved in proliferation and angiogenesis. The marker was designed to target proliferating smooth muscle cells expressing tissue factor ${ }^{56}$. Apoptosis is a key process in many malignant progressions, such as cancer, chronic inflammation and atherosclerosis. The membrane translocation of the apoptosis marker phosphatidylserine (PS) was targeted in two ways: the design of fluorescent CLIO particles with annexin $\mathrm{V}^{102}$ and the synthesis of annexin $\mathrm{V}$-conjugated gadolinium or iron liposome containing quantum dots for dual MRI and optical detection ${ }^{103,104}$.

\section{Thrombosis}

The final process is thrombosis, which can be detected either by natural MR contrast of methemoglobin ${ }^{34,105,106}$ or by specific fibrin markers ${ }^{106-110}$. For fibrin marker validation, proof of concept and validation steps include imaging of fibrin labeled clots, in vitro experiments and in vivo administration ${ }^{107,109,110}$. Perfluorocarbon particles enabled enhanced specificity by additional ${ }^{19} \mathrm{~F}$ MRI ${ }^{110}$.

Each new MR marker validation involves the following steps: 1/ establishing the relevance of the chosen strategy in terms of targeting and specificity of the newly synthesized compound; 2/ MRI detection of the marker and the limit of sensitivity; 3/ co-location of the marker with the target, confirmed by experimentally enhanced target expression or by in vitro and in vivo competition protocols; and 4/ in vivo validation after a systemic injection with careful examination of pharmacokinetic profile and discrimination from non-specific enhancement (for gadolinium) or background noise (for iron particles). The first three phases are shared by any sensor and have been handled with optical probes in confocal microscopy. This is one reason for associating the gadolinium or iron marker with a fluorophore in the development of new MR markers. The second reason is the lack of sensitivity with MRI. For gadolinium contrast agents, the limit for one gadolinium unit is usually in the micromolar range. Sensitivity can be increased to the nanomolar or even the picomolar range by increasing the relaxivity per gadolinium unit (high relaxivity agents) and by formulation with a high payload of gadolinium per binding molecule (macromolecules, gadolinium nanoparticles or gadolinium liposomes) ${ }^{56}$. Another way is to choose a target with a large number of binding sites, such as fibrin ${ }^{108}$. For iron oxide particles, the susceptibility effect is more powerful than the paramagnetic effect and iron particles are already loaded with multiple irons, with an in vitro detection limit in the nano- to pico-molar range. However, in vivo detection with iron oxide particles requires careful protocols, as a dark spot is more difficult to interpret than a 
bright spot. Thus, the specificity of in vivo iron oxide imaging is MR-sequence-dependent and new detection strategies are still under intense investigation ${ }^{78,79}$.

\section{Limitations to the clinical use of Gd-based and iron-based platforms for molecular imaging in atherosclerosis}

From the increasing amount of experimental data on atherosclerosis and targeted MR contrast agents, several limitations can be identified.

First, for gadolinium-based markers, non-specific uptake due to increased inflammatory tissue permeability makes a dynamic follow-up from one hour to 24 hours post-injection mandatory, to highlight differences between non-specific and specific enhancement. The poor sensitivity of MRI is also an important limitation when using gadolinium agents. An optimal balance has to be found between the number of gadolinium unit per macromolecule (i.e., >100), the stability of the gadolinium complex, a high relaxivity per gadolinium unit and conserved macromolecule $\mathrm{r} 1$ relaxivity at high magnetic field. The poor sensitivity also limits the choice of target, which needs to have a high expression level in the lesion.

The steric hindrance of these gadolinium platforms (nanoparticles $>100 \mathrm{~nm}$ ) determines specific routes for biodistribution and clearance, and sets limits to extracellular targets. Moreover, clinical applications will be subject to safety concerns: i.e., liver uptake and Gd complex stability, which will have to be determined as a function of formulation and biodistribution. For clinical applications, cheap and easy chemistry will also be a major concern for synthesis scale-up.

The limitations with iron oxide particles lie mainly in their negative effect on the signal and in the lack of quantification. On gradient echo, small signal loss at short TE is difficult to discriminate from artifacts: a long TE gives larger susceptibility effects but with poor image quality and location. In animal compared to human studies, larger USPIO doses are injected (typically, $45 \mu \mathrm{mol} \mathrm{Fe} / \mathrm{kg}$ in humans versus 200 to $1,000 \mu \mathrm{mol} \mathrm{Fe} / \mathrm{kg}$ in animals). The interspecies variability of USPIOs' blood half life and pharmacokinetics, which are also dose dependent (partly by saturation of the reticulo-endothelial system), makes it difficult to extrapolate experimental results to clinical findings. By testing different USPIO preparations, it has been shown that prolonged blood residence facilitates penetration into deep compartments such as atherosclerotic lesions; but a long delay between injection and the imaging window is then a major issue for clinical application. The time after injection to allow the signal from blood to decrease as well as the non-specific distribution by permeability gives an acquisition window that may be delayed by as long as 5-7 days after 
USPIO administration. Lastly, for clinical applications, long-term follow-up of iron nanoparticle biotransformation, and of the fate of iron-labeled cells, will be required to fully understand their behavior in inflammatory tissue.

The ultimate goal for clinical diagnosis is to characterize vulnerable plaque by molecular imaging. Plaque rupture is a major cause of atherothrombosis; unfortunately there is no animal model for plaque rupture with consequences such as sudden death, brain or myocardial infarction. Plaque rupture has been reported in the innominate artery of ApoE KO mice, but the interval between thrombus formation and thrombolysis is much shorter than in humans, making it very difficult to observe ${ }^{111-114}$; also, the thrombus is very small in mice compared to humans. Defining vulnerable plaque in animal models has to take account of these kinetic factors, and plaque vulnerability biomarkers also need to adapt to such interspecies differences. In the literature, the ApoE KO mouse is the most common animal model of atherosclerosis, often using a western diet for up to 6 months to study inflammation and the key processes involved in plaque vulnerability. Another animal model is the Watanabe rabbit, which also has to be fed a high-fat diet to increase plaque inflammation. For vessel wall inflammation in the rabbit, the alternative is a surgically induced endothelial lesion, together with a high fat diet. Depending on the animal model used, very different results are observed, as shown with USPIOs ${ }^{63-66,68-70,115}$.

\section{Conclusion}

The present review deals with the interplay between the complex vascular biology involved in plaque formation, inflammation and atherothrombosis and the potential role of MR contrast agents in this interplay. We focused on inflammation and adhesion molecules to illustrate their high potential for molecular imaging with MRI. They can be injected directly, both to target elements in the blood stream, as adhesion molecules are present both at the surface of immune cells and platelets, and to characterize the vessel wall, as they are highly expressed on activated endothelium and plaque components. Moreover, a growing body of evidence shows their importance in advanced lesions as a link between inflammation and immune response on the one hand and thrombosis on the other. The triggering sequence leading to plaque rupture is still a matter of debate. In humans, the definition of vulnerable plaque is moving towards a more integrated vision of the vulnerable patient. In animal models, plaque rupture is rarely seen, and moreover shows interspecies differences that have to be taken into account in defining plaque vulnerability. Bringing molecular imaging and vascular biology 
together will provide new information on dynamic processes, such as inflammation and thrombogenesis.

Due to its contrast flexibility and its high spatial resolution, MRI is a promising new technique for the characterization of inflammation in atherosclerosis. MRI of intraplaque macrophage activity using iron oxide particles is already under clinical investigation. Processes such as oxidative stress, proliferation, apoptosis and thrombogenesis were recently investigated by MRI. A fibrin marker for the diagnosis of thrombosis is under development for clinical trials. Newly designed gadolinium or iron oxide MR markers for molecular imaging have targeted integrins, immunoglobulins and selectins to characterize vessel wall inflammation and angiogenesis, but still have certain limitations for application in large-scale clinical trials

In conclusion, molecular MRI of atherosclerosis is still in its infancy, and numerous targets and imaging strategies remain to be explored in close collaboration with molecular biologists. Information needs to be gathered from multiple modalities and experimental models to deal with the different facets of this complex chronic vascular disease. 
Grant sponsors: This work was supported by the French Ministry of Research (Incentive Concerted Action Program, project CIVAREM), Rhône-Alpes Region grants, and an Ile de France and Paris Region ATHIM grant (Medicen Santé Ile de France cluster). 


\section{References:}

1. Stary HC, Chandler AB, Dinsmore RE, Fuster V, Glagov S, Insull W, Jr., Rosenfeld ME, Schwartz CJ, Wagner WD, Wissler RW. A definition of advanced types of atherosclerotic lesions and a histological classification of atherosclerosis. A report from the Committee on Vascular Lesions of the Council on Arteriosclerosis, American Heart Association. Circulation. 1995;92:1355-74.

2. Aikawa M, Libby P. The vulnerable atherosclerotic plaque: pathogenesis and therapeutic approach. Cardiovasc Pathol. 2004;13:125-38.

3. Libby P. Inflammation in atherosclerosis. Nature. 2002;420:868-74.

4. Mullenix PS, Andersen CA, Starnes BW. Atherosclerosis as inflammation. Ann Vasc Surg. 2005; 19:130-8.

5. Lucas AR, Korol R, Pepine CJ. Inflammation in atherosclerosis: some thoughts about acute coronary syndromes. Circulation. 2006;113:e728-32.

6. Danesh J, Wheeler JG, Hirschfield GM, Eda S, Eiriksdottir G, Rumley A, Lowe GD, Pepys MB, Gudnason V. C-reactive protein and other circulating markers of inflammation in the prediction of coronary heart disease. $N$ Engl J Med. 2004;350:1387-97.

7. Chamorro A, Hallenbeck J. The harms and benefits of inflammatory and immune responses in vascular disease. Stroke. 2006;37:291-3.

8. Bonora E. The metabolic syndrome and cardiovascular disease. Ann Med. 2006;38:64-80.

9. Ballantyne CM, Nambi V. Markers of inflammation and their clinical significance. Atheroscler Suppl. 2005;6:21-9.

10. Armstrong EJ, Morrow DA, Sabatine MS. Inflammatory biomarkers in acute coronary syndromes: part IV: matrix metalloproteinases and biomarkers of platelet activation. Circulation. 2006;113:e382-5.

11. Armstrong EJ, Morrow DA, Sabatine MS. Inflammatory biomarkers in acute coronary syndromes: part I: introduction and cytokines. Circulation. 2006;113:e72-5.

12. Armstrong EJ, Morrow DA, Sabatine MS. Inflammatory biomarkers in acute coronary syndromes: part II: acute-phase reactants and biomarkers of endothelial cell activation. Circulation. 2006;113:e152-5.

13. Armstrong EJ, Morrow DA, Sabatine MS. Inflammatory biomarkers in acute coronary syndromes: part III: biomarkers of oxidative stress and angiogenic growth factors. Circulation. 2006;113:e289-92.

14. Koh KK, Han SH, Quon MJ. Inflammatory markers and the metabolic syndrome: insights from therapeutic interventions. J Am Coll Cardiol. 2005;46:1978-85.

15. Furie B, Furie BC. Thrombus formation in vivo. J Clin Invest. 2005;115:3355-62.

16. Gawaz M, Langer H, May AE. Platelets in inflammation and atherogenesis. $J$ Clin Invest. 2005;115:3378-84.

17. Frenette PS, Johnson RC, Hynes RO, Wagner DD. Platelets roll on stimulated endothelium in vivo: an interaction mediated by endothelial P-selectin. Proc Natl Acad Sci U S A. 1995;92:7450-4.

18. McEver RP. P-selectin and PSGL-1: exploiting connections between inflammation and venous thrombosis. Thromb Haemost. 2002;87:364-5.

19. McEver RP, Cummings RD. Perspectives series: cell adhesion in vascular biology. Role of PSGL-1 binding to selectins in leucocyte recruitment. J Clin Invest. 1997;100:485-91.

20. Lopez JA, Dong JF. Structure and function of the glycoprotein Ib-IX-V complex. Curr Opin Hematol. 1997;4:323-9.

21. Dong JF, Sae-Tung G, Lopez JA. Role of glycoprotein V in the formation of the platelet highaffinity thrombin-binding site. Blood. 1997;89:4355-63.

22. Blondin C, Bataille I, Letourneur D. Polysaccharides for vascular cell targeting. Crit Rev Ther Drug Carrier Syst. 2000;17:327-75.

23. Elangbam CS, Qualls CW, Jr., Dahlgren RR. Cell adhesion molecules--update. Vet Pathol. 1997;34:61-73.

24. Lasky LA. Selectin-carbohydrate interactions and the initiation of the inflammatory response. Annu Rev Biochem. 1995;64:113-39. 
25. Esko JD, Zhang L. Influence of core protein sequence on glycosaminoglycan assembly. Curr Opin Struct Biol. 1996;6:663-70.

26. Wu JT, Wu LL. Linking inflammation and atherogenesis: Soluble markers identified for the detection of risk factors and for early risk assessment. Clin Chim Acta. 2006;366:74-80.

27. Lynch JR, Blessing R, White WD, Grocott HP, Newman MF, Laskowitz DT. Novel diagnostic test for acute stroke. Stroke. 2004;35:57-63.

28. Jaffer FA, Libby P, Weissleder R. Molecular and cellular imaging of atherosclerosis: emerging applications. J Am Coll Cardiol. 2006;47:1328-38.

29. Tedgui A, Mallat Z. Cytokines in atherosclerosis: pathogenic and regulatory pathways. Physiol Rev. 2006;86:515-81.

30. Stokes KY, Granger DN. The microcirculation: a motor for the systemic inflammatory response and large vessel disease induced by hypercholesterolaemia? J Physiol. 2005;562:647-53.

31. Gupta AK, Gupta M. Synthesis and surface engineering of iron oxide nanoparticles for biomedical applications. Biomaterials. 2005;26:3995-4021.

32. Nighoghossian N, Derex L, Douek P. The vulnerable carotid artery plaque: current imaging methods and new perspectives. Stroke. 2005;36:2764-72.

33. Corti R. Noninvasive imaging of atherosclerotic vessels by MRI for clinical assessment of the effectiveness of therapy. Pharmacol Ther. 2006;110:57-70.

34. Rutt BK, Clarke SE, Fayad ZA. Atherosclerotic plaque characterization by MR imaging. Curr Drug Targets Cardiovasc Haematol Disord. 2004;4:147-59.

35. Spuentrup E, Botnar RM. Coronary magnetic resonance imaging: visualization of the vessel lumen and the vessel wall and molecular imaging of arteriothrombosis. Eur Radiol. 2006;16:1-14.

36. Clarke SE, Hammond RR, Mitchell JR, Rutt BK. Quantitative assessment of carotid plaque composition using multicontrast MRI and registered histology. Magn Reson Med. 2003;50:1199-208.

37. Clarke SE, Beletsky V, Hammond RR, Hegele RA, Rutt BK. Validation of automatically classified magnetic resonance images for carotid plaque compositional analysis. Stroke. 2006;37:93-7.

38. Saam T, Cai JM, Cai YQ, An NY, Kampschulte A, Xu D, Kerwin WS, Takaya N, Polissar NL, Hatsukami TS, Yuan C. Carotid plaque composition differs between ethno-racial groups: an MRI pilot study comparing mainland Chinese and American Caucasian patients. Arterioscler Thromb Vasc Biol. 2005;25:611-6.

39. Itskovich VV, Samber DD, Mani V, Aguinaldo JG, Fallon JT, Tang CY, Fuster V, Fayad ZA. Quantification of human atherosclerotic plaques using spatially enhanced cluster analysis of multicontrast-weighted magnetic resonance images. Magn Reson Med. 2004;52:515-23.

40. Yuan C, Mitsumori LM, Beach KW, Maravilla KR. Carotid atherosclerotic plaque: noninvasive MR characterization and identification of vulnerable lesions. Radiology. 2001;221:285-99.

41. Cappendijk VC, Cleutjens KB, Kessels AG, Heeneman S, Schurink GW, Welten RJ, Mess WH, Daemen MJ, van Engelshoven JM, Kooi ME. Assessment of human atherosclerotic carotid plaque components with multisequence MR imaging: initial experience. Radiology. 2005;234:487-92.

42. Wasserman BA, Smith WI, Trout HH, 3rd, Cannon RO, 3rd, Balaban RS, Arai AE. Carotid artery atherosclerosis: in vivo morphologic characterization with gadolinium-enhanced double-oblique MR imaging initial results. Radiology. 2002;223:566-73.

43. Yuan C, Kerwin WS, Ferguson MS, Polissar N, Zhang S, Cai J, Hatsukami TS. Contrastenhanced high resolution MRI for atherosclerotic carotid artery tissue characterization. $J$ Magn Reson Imaging. 2002;15:62-7.

44. Wasserman BA, Wityk RJ, Trout HH, 3rd, Virmani R. Low-grade carotid stenosis: looking beyond the lumen with MRI. Stroke. 2005;36:2504-13.

45. Cai J, Hatsukami TS, Ferguson MS, Kerwin WS, Saam T, Chu B, Takaya N, Polissar NL, Yuan C. In vivo quantitative measurement of intact fibrous cap and lipid-rich necrotic core 
size in atherosclerotic carotid plaque: comparison of high-resolution, contrast-enhanced magnetic resonance imaging and histology. Circulation. 2005;112:3437-44.

46. Kerwin WS, O'Brien KD, Ferguson MS, Polissar N, Hatsukami TS, Yuan C. Inflammation in carotid atherosclerotic plaque: a dynamic contrast-enhanced MR imaging study. Radiology. 2006;241:459-68.

47. Yuan C, Kerwin WS, Yarnykh VL, Cai J, Saam T, Chu B, Takaya N, Ferguson MS, Underhill $\mathrm{H}, \mathrm{Xu} \mathrm{D}$, Liu F, Hatsukami TS. MRI of atherosclerosis in clinical trials. NMR Biomed. 2006;19:636-54.

48. Yarnykh VL, Terashima M, Hayes CE, Shimakawa A, Takaya N, Nguyen PK, Brittain JH, McConnell MV, Yuan C. Multicontrast black-blood MRI of carotid arteries: comparison between 1.5 and 3 tesla magnetic field strengths. J Magn Reson Imaging. 2006;23:691-8.

49. Kelly KA, Allport JR, Tsourkas A, Shinde-Patil VR, Josephson L, Weissleder R. Detection of vascular adhesion molecule-1 expression using a novel multimodal nanoparticle. Circ Res. 2005;96:327-36.

50. Kerwin W, Hooker A, Spilker M, Vicini P, Ferguson M, Hatsukami T, Yuan C. Quantitative magnetic resonance imaging analysis of neovasculature volume in carotid atherosclerotic plaque. Circulation. 2003;107:851-6.

51. Mani V, Itskovich VV, Aguiar SH, Mizsei G, Aguinaldo JG, Samber DD, Macaluso FM, Fayad ZA. Comparison of gated and non-gated fast multislice black-blood carotid imaging using rapid extended coverage and inflow/outflow saturation techniques. J Magn Reson Imaging. 2005;22:628-33.

52. Thomas JB, Jong L, Spence JD, Wasserman BA, Rutt BK, Steinman DA. Anthropometric data for magnetic resonance imaging of the carotid bifurcation. J Magn Reson Imaging. 2005;21:845-9.

53. Yarnykh VL, Yuan C. Simultaneous outer volume and blood suppression by quadruple inversion-recovery. Magn Reson Med. 2006;55:1083-92.

54. Allkemper T, Bremer C, Matuszewski L, Ebert W, Reimer P. Contrast-enhanced blood-pool MR angiography with optimized iron oxides: effect of size and dose on vascular contrast enhancement in rabbits. Radiology. 2002;223:432-8.

55. Chaabane L, Pellet N, Bourdillon MC, Desbleds Mansard C, Sulaiman A, Hadour G, Thivolet-Bejui F, Roy P, Briguet A, Douek P, Canet Soulas E. Contrast enhancement in atherosclerosis development in a mouse model: in vivo results at 2 Tesla. Magn Reson Mater Phy. 2004;17:188-95.

56. Morawski AM, Winter PM, Crowder KC, Caruthers SD, Fuhrhop RW, Scott MJ, Robertson JD, Abendschein DR, Lanza GM, Wickline SA. Targeted nanoparticles for quantitative imaging of sparse molecular epitopes with MRI. Magn Reson Med. 2004;51:480-6.

57. Wickline SA, Neubauer AM, Winter P, Caruthers S, Lanza G. Applications of nanotechnology to atherosclerosis, thrombosis, and vascular biology. Arterioscler Thromb Vasc Biol. 2006;26:435-41.

58. Mulder WJ, Strijkers GJ, van Tilborg GA, Griffioen AW, Nicolay K. Lipid-based nanoparticles for contrast-enhanced MRI and molecular imaging. NMR Biomed. 2006;19:14264 .

59. Roch A, Muller RN, Gillis P. Theory of proton relaxation induced by superparamagnetic particles. J Chem Phys. 1999;110:5403-5411.

60. Roch A, Muller RN, Gillis P. Water relaxation by SPM particles: neglecting the magnetic anisotropy? A caveat. J Magn Reson Imaging. 2001;14:94-6.

61. Simon GH, Bauer J, Saborovski O, Fu Y, Corot C, Wendland MF, Daldrup-Link HE. T1 and $\mathrm{T} 2$ relaxivity of intracellular and extracellular USPIO at $1.5 \mathrm{~T}$ and $3 \mathrm{~T}$ clinical MR scanning. Eur Radiol. 2006;16:738-45.

62. Riviere C, Boudghene FP, Gazeau F, Roger J, Pons JN, Laissy JP, Allaire E, Michel JB, Letourneur D, Deux JF. Iron oxide nanoparticle-labeled rat smooth muscle cells: cardiac MR imaging for cell graft monitoring and quantitation. Radiology. 2005;235:959-67.

63. Schmitz SA, Coupland SE, Gust R, Winterhalter S, Wagner S, Kresse M, Semmler W, Wolf KJ. Superparamagnetic iron oxide-enhanced MRI of atherosclerotic plaques in Watanabe hereditable hyperlipidemic rabbits. Invest Radiol. 2000;35:460-71. 
64. Ruehm SG, Corot C, Vogt P, Kolb S, Debatin JF. Magnetic resonance imaging of atherosclerotic plaque with ultrasmall superparamagnetic particles of iron oxide in hyperlipidemic rabbits. Circulation. 2001;103:415-22.

65. Schmitz SA, Taupitz M, Wagner S, Coupland SE, Gust R, Nikolova A, Wolf KJ. Iron-oxideenhanced magnetic resonance imaging of atherosclerotic plaques: postmortem analysis of accuracy, inter-observer agreement, and pitfalls. Invest Radiol. 2002;37:405-11.

66. Yancy AD, Olzinski AR, Hu TC, Lenhard SC, Aravindhan K, Gruver SM, Jacobs PM, Willette RN, Jucker BM. Differential uptake of ferumoxtran-10 and ferumoxytol, ultrasmall superparamagnetic iron oxide contrast agents in rabbit: critical determinants of atherosclerotic plaque labeling. J Magn Reson Imaging. 2005;21:432-42.

67. Rogers WJ, Basu P. Factors regulating macrophage endocytosis of nanoparticles: implications for targeted magnetic resonance plaque imaging. Atherosclerosis. 2005;178:67-73.

68. Hyafil F, Laissy JP, Mazighi M, Tchetche D, Louedec L, Adle-Biassette H, Chillon S, Henin D, Jacob MP, Letourneur D, Feldman LJ. Ferumoxtran-10-enhanced MRI of the hypercholesterolemic rabbit aorta: relationship between signal loss and macrophage infiltration. Arterioscler Thromb Vasc Biol. 2006;26:176-81.

69. Herborn CU, Vogt FM, Lauenstein TC, Dirsch O, Corot C, Robert P, Ruehm SG. Magnetic resonance imaging of experimental atherosclerotic plaque: Comparison of two ultrasmall superparamagnetic particles of iron oxide. J Magn Reson Imaging. 2006.

70. Litovsky S, Madjid M, Zarrabi A, Casscells SW, Willerson JT, Naghavi M. Superparamagnetic iron oxide-based method for quantifying recruitment of monocytes to mouse atherosclerotic lesions in vivo: enhancement by tissue necrosis factor-alpha, interleukin-1beta, and interferon-gamma. Circulation. 2003;107:1545-9.

71. Schmitz SA, Taupitz M, Wagner S, Wolf KJ, Beyersdorff D, Hamm B. Magnetic resonance imaging of atherosclerotic plaques using superparamagnetic iron oxide particles. J Magn Reson Imaging. 2001;14:355-61.

72. Kooi ME, Cappendijk VC, Cleutjens KB, Kessels AG, Kitslaar PJ, Borgers M, Frederik PM, Daemen MJ, van Engelshoven JM. Accumulation of ultrasmall superparamagnetic particles of iron oxide in human atherosclerotic plaques can be detected by in vivo magnetic resonance imaging. Circulation. 2003;107:2453-8.

73. Trivedi RA, JM UK-I, Graves MJ, Kirkpatrick PJ, Gillard JH. Noninvasive imaging of carotid plaque inflammation. Neurology. 2004;63:187-8.

74. Trivedi RA, Mallawarachi C, JM UK-I, Graves MJ, Horsley J, Goddard MJ, Brown A, Wang L, Kirkpatrick PJ, Brown J, Gillard JH. Identifying inflamed carotid plaques using in vivo USPIO-enhanced MR imaging to label plaque macrophages. Arterioscler Thromb Vasc Biol. 2006;26:1601-6.

75. Tang T, Howarth SP, Miller SR, Trivedi R, Graves MJ, King-Im JU, Li ZY, Brown AP, Kirkpatrick PJ, Gaunt ME, Gillard JH. Assessment of inflammatory burden contralateral to the symptomatic carotid stenosis using high-resolution ultrasmall, superparamagnetic iron oxideenhanced MRI. Stroke. 2006;37:2266-70.

76. Corot C, Robert P, Idee JM, Port M. Recent advances in iron oxide nanocrystal technology for medical imaging. Adv Drug Deliv Rev. 2006;58:1471-504.

77. Wiart M, Davoust N, Pialat JB, Desestret V, Moucharaffie S, Cho TH, Mutin M, Langlois JB, Beuf O, Honnorat J, Nighoghossian N, Berthezene Y. MRI monitoring of neuroinflammation in mouse focal ischemia. Stroke. 2007;38:131-7.

78. Mani V, Briley-Saebo KC, Itskovich VV, Samber DD, Fayad ZA. Gradient echo acquisition for superparamagnetic particles with positive contrast (GRASP): sequence characterization in membrane and glass superparamagnetic iron oxide phantoms at 1.5T and 3T. Magn Reson Med. 2006;55:126-35.

79. Heyn C, Bowen CV, Rutt BK, Foster PJ. Detection threshold of single SPIO-labeled cells with FIESTA. Magn Reson Med. 2005;53:312-20.

80. Swirski FK, Pittet MJ, Kircher MF, Aikawa E, Jaffer FA, Libby P, Weissleder R. Monocyte accumulation in mouse atherogenesis is progressive and proportional to extent of disease. Proc Natl Acad Sci U S A. 2006;103:10340-5. 
81. Mulder WJ, Douma K, Koning GA, van Zandvoort MA, Lutgens E, Daemen MJ, Nicolay K, Strijkers GJ. Liposome-enhanced MRI of neointimal lesions in the ApoE-KO mouse. Magn Reson Med. 2006;55:1170-1174.

82. Briley-Saebo KC, Amirbekian V, Mani V, Aguinaldo JG, Vucic E, Carpenter D, Amirbekian S, Fayad ZA. Gadolinium mixed-micelles: effect of the amphiphile on in vitro and in vivo efficacy in apolipoprotein E knockout mouse models of atherosclerosis. Magn Reson Med. 2006;56:1336-46.

83. Tsourkas A, Shinde-Patil VR, Kelly KA, Patel P, Wolley A, Allport JR, Weissleder R. In vivo imaging of activated endothelium using an anti-VCAM-1 magnetooptical probe. Bioconjug Chem. 2005;16:576-81.

84. Kang HW, Josephson L, Petrovsky A, Weissleder R, Bogdanov A, Jr. Magnetic resonance imaging of inducible E-selectin expression in human endothelial cell culture. Bioconjug Chem. 2002; 13:122-7.

85. Laurent $\mathrm{S}$, Vander Elst L, Fu Y, Muller RN. Synthesis and physicochemical characterization of Gd-DTPA-B(sLex)A, a new MRI contrast agent targeted to inflammation. Bioconjug Chem. 2004;15:99-103.

86. Boutry S, Burtea C, Laurent S, Toubeau G, Vander Elst L, Muller RN. Magnetic resonance imaging of inflammation with a specific selectin-targeted contrast agent. Magn Reson Med. 2005;53:800-7.

87. Sibson NR, Blamire AM, Bernades-Silva M, Laurent S, Boutry S, Muller RN, Styles P, Anthony DC. MRI detection of early endothelial activation in brain inflammation. Magn Reson Med. 2004;51:248-52.

88. Winter PM, Neubauer AM, Caruthers SD, Harris TD, Robertson JD, Williams TA, Schmieder AH, Hu G, Allen JS, Lacy EK, Wickline SA, Lanza GM. Endothelial \{alpha\} \{nu\} \{beta 3 Integrin-Targeted Fumagillin Nanoparticles Inhibit Angiogenesis in Atherosclerosis. Arterioscler Thromb Vasc Biol. 2006.

89. Winter PM, Morawski AM, Caruthers SD, Fuhrhop RW, Zhang H, Williams TA, Allen JS, Lacy EK, Robertson JD, Lanza GM, Wickline SA. Molecular imaging of angiogenesis in early-stage atherosclerosis with alpha(v)beta3-integrin-targeted nanoparticles. Circulation. 2003;108:2270-4.

90. Anderson SA, Rader RK, Westlin WF, Null C, Jackson D, Lanza GM, Wickline SA, Kotyk JJ. Magnetic resonance contrast enhancement of neovasculature with alpha(v)beta(3)-targeted nanoparticles. Magn Reson Med. 2000;44:433-9.

91. Nahrendorf M, Jaffer FA, Kelly KA, Sosnovik DE, Aikawa E, Libby P, Weissleder R. Noninvasive vascular cell adhesion molecule-1 imaging identifies inflammatory activation of cells in atherosclerosis. Circulation. 2006;114:1504-11.

92. Alsaid H, De Souza G, Bourdillon MC, Chaubet F, Sulaiman A, Zahir C, Lancelot E, Briguet A, Letourneur D, Canet-Soulas E. Molecular Imaging of Inflammation in Atherosclerosis Plaque Using Functionalized MRI Contrast Agent. In: Proc. Intl. Soc. Mag. Reson. Med., 14. Seattle; 2006:3506.

93. Burtea C, Laurent S, Roch A, Vander Elst L, Muller RN. C-MALISA (cellular magneticlinked immunosorbent assay), a new application of cellular ELISA for MRI. J Inorg Biochem. 2005;99:1135-44.

94. Montet X, Montet-Abou K, Reynolds F, Weissleder R, Josephson L. Nanoparticle imaging of integrins on tumor cells. Neoplasia. 2006;8:214-22.

95. Li H, Gray BD, Corbin I, Lebherz C, Choi H, Lund-Katz S, Wilson JM, Glickson JD, Zhou R. MR and fluorescent imaging of low-density lipoprotein receptors. Acad Radiol. 2004;11:12519.

96. Sirol M, Itskovich VV, Mani V, Aguinaldo JG, Fallon JT, Misselwitz B, Weinmann HJ, Fuster V, Toussaint JF, Fayad ZA. Lipid-rich atherosclerotic plaques detected by gadofluorine-enhanced in vivo magnetic resonance imaging. Circulation. 2004;109:2890-6.

97. Frias JC, Williams KJ, Fisher EA, Fayad ZA. Recombinant HDL-like nanoparticles: a specific contrast agent for MRI of atherosclerotic plaques. J Am Chem Soc. 2004;126:16316-7.

98. Amirbekian V, Lipinski MJ, Briley-Saebo KC, Amirbekian S, Aguinaldo JG, Weinreb DB, Vucic E, Frias JC, Hyafil F, Mani V, Fisher EA, Fayad ZA. Detecting and assessing 
macrophages in vivo to evaluate atherosclerosis noninvasively using molecular MRI. Proc Natl Acad Sci U S A. 2007;104:961-6.

99. Amirbekian S, Aguinaldo JS, Amirbekian V, Sirol M, Hyafil F, Vucic E, Mani V, Lancelot E, Corot C, Fayad Z. Imaging of Atherosclerosis In Vivo Using a Magnetic Resonance Contrast Probe Molecularly Targeted to Matrix Metalloproteinases (MMPs). In: Proc. Intl. Soc. Mag. Reson. Med., 14. Seattle; 2006:559.

100. Chen JW, Pham W, Weissleder R, Bogdanov A, Jr. Human myeloperoxidase: a potential target for molecular MR imaging in atherosclerosis. Magn Reson Med. 2004;52:1021-8.

101. Lanza GM, Yu X, Winter PM, Abendschein DR, Karukstis KK, Scott MJ, Chinen LK, Fuhrhop RW, Scherrer DE, Wickline SA. Targeted antiproliferative drug delivery to vascular smooth muscle cells with a magnetic resonance imaging nanoparticle contrast agent: implications for rational therapy of restenosis. Circulation. 2002;106:2842-7.

102. Sosnovik DE, Schellenberger EA, Nahrendorf M, Novikov MS, Matsui T, Dai G, Reynolds F, Grazette L, Rosenzweig A, Weissleder R, Josephson L. Magnetic resonance imaging of cardiomyocyte apoptosis with a novel magneto-optical nanoparticle. Magn Reson Med. 2005;54:718-24.

103. van Tilborg GA, Mulder WJ, Chin PT, Storm G, Reutelingsperger CP, Nicolay K, Strijkers GJ. Annexin A5-Conjugated Quantum Dots with a Paramagnetic Lipidic Coating for the Multimodal Detection of Apoptotic Cells. Bioconjug Chem. 2006;17:865-868.

104. van Tilborg GA, Mulder WJ, Deckers N, Storm G, Reutelingsperger CP, Strijkers GJ, Nicolay K. Annexin A5-functionalized bimodal lipid-based contrast agents for the detection of apoptosis. Bioconjug Chem. 2006;17:741-9.

105. Moody AR, Allder S, Lennox G, Gladman J, Fentem P. Direct magnetic resonance imaging of carotid artery thrombus in acute stroke. Lancet. 1999;353:122-3.

106. Corti R, Osende JI, Fayad ZA, Fallon JT, Fuster V, Mizsei G, Dickstein E, Drayer B, Badimon JJ. In vivo noninvasive detection and age definition of arterial thrombus by MRI. $J$ Am Coll Cardiol. 2002;39:1366-73.

107. Botnar RM, Buecker A, Wiethoff AJ, Parsons EC, Jr., Katoh M, Katsimaglis G, Weisskoff RM, Lauffer RB, Graham PB, Gunther RW, Manning WJ, Spuentrup E. In vivo magnetic resonance imaging of coronary thrombosis using a fibrin-binding molecular magnetic resonance contrast agent. Circulation. 2004;110:1463-6.

108. Botnar RM, Perez AS, Witte S, Wiethoff AJ, Laredo J, Hamilton J, Quist W, Parsons EC, Jr., Vaidya A, Kolodziej A, Barrett JA, Graham PB, Weisskoff RM, Manning WJ, Johnstone MT. In vivo molecular imaging of acute and subacute thrombosis using a fibrin-binding magnetic resonance imaging contrast agent. Circulation. 2004;109:2023-9.

109. Flacke S, Fischer S, Scott MJ, Fuhrhop RJ, Allen JS, McLean M, Winter P, Sicard GA, Gaffney PJ, Wickline SA, Lanza GM. Novel MRI contrast agent for molecular imaging of fibrin: implications for detecting vulnerable plaques. Circulation. 2001;104:1280-5.

110. Morawski AM, Winter PM, Yu X, Fuhrhop RW, Scott MJ, Hockett F, Robertson JD, Gaffney PJ, Lanza GM, Wickline SA. Quantitative "magnetic resonance immunohistochemistry" with ligand-targeted (19)F nanoparticles. Magn Reson Med. 2004;52:1255-62.

111. Coleman R, Hayek T, Keidar S, Aviram M. A mouse model for human atherosclerosis: longterm histopathological study of lesion development in the aortic arch of apolipoprotein Edeficient (E0) mice. Acta Histochem. 2006;108:415-24.

112. Schwartz SM, Galis ZS, Rosenfeld ME, Falk E. Plaque rupture in humans and mice. Arterioscler Thromb Vasc Biol. 2007;27:705-13.

113. Meir KS, Leitersdorf E. Atherosclerosis in the apolipoprotein-E-deficient mouse: a decade of progress. Arterioscler Thromb Vasc Biol. 2004;24:1006-14.

114. Jackson CL, Bennett MR, Biessen EA, Johnson JL, Krams R. Assessment of unstable atherosclerosis in mice. Arterioscler Thromb Vasc Biol. 2007;27:714-20.

115. Priest AN, Ittrich $\mathrm{H}$, Jahntz $\mathrm{CL}$, Kooijman $\mathrm{H}$, Weber $\mathrm{C}$, Adam G. Investigation of atherosclerotic plaques with MRI at $3 \mathrm{~T}$ using ultrasmall superparamagnetic particles of iron oxide. Magn Reson Imaging. 2006;24:1287-93.

116. Chaabane L, Canet E, Serfaty JM, Contard F, Guerrier D, Douek P, Briguet A. Microimaging of atherosclerotic plaque in animal models. Magn Reson Mater Phy. 2000;11:58-60. 
117. Lipinski MJ, Amirbekian V, Frias JC, Aguinaldo JG, Mani V, Briley-Saebo KC, Fuster V, Fallon JT, Fisher EA, Fayad ZA. MRI to detect atherosclerosis with gadolinium-containing immunomicelles targeting the macrophage scavenger receptor. Magn Reson Med. 2006;56:601-10.

118. Aikawa E, Nahrendorf M, Sosnovik D, Lok VM, Jaffer FA, Aikawa M, Weissleder R. Multimodality molecular imaging identifies proteolytic and osteogenic activities in early aortic valve disease. Circulation. 2007;115:377-86.

119. Jaffer FA, Nahrendorf M, Sosnovik D, Kelly KA, Aikawa E, Weissleder R. Cellular imaging of inflammation in atherosclerosis using magnetofluorescent nanomaterials. Mol Imaging. 2006;5:85-92.

120. von Zur Muhlen C, von Elverfeldt D, Bassler N, Neudorfer I, Steitz B, Petri-Fink A, Hofmann $\mathrm{H}$, Bode C, Peter K. Superparamagnetic iron oxide binding and uptake as imaged by magnetic resonance is mediated by the integrin receptor Mac-1 (CD11b/CD18): Implications on imaging of atherosclerotic plaques. Atherosclerosis. 2006.

121. Deguchi JO, Aikawa M, Tung CH, Aikawa E, Kim DE, Ntziachristos V, Weissleder R, Libby P. Inflammation in atherosclerosis: visualizing matrix metalloproteinase action in macrophages in vivo. Circulation. 2006;114:55-62.

122. Winter PM, Caruthers SD, Yu X, Song SK, Chen J, Miller B, Bulte JW, Robertson JD, Gaffney PJ, Wickline SA, Lanza GM. Improved molecular imaging contrast agent for detection of human thrombus. Magn Reson Med. 2003;50:411-6. 
Abbreviations and Acronyms

CAM = cell adhesion molecule (ICAM, VCAM, Selectins)

CD44 = lymphocyte integrin, interaction with extracellular matrix (hyaluronan)

CR3 or $4=$ complement receptors for fragments 3 and 4 expressed on monocytes

$\mathrm{CRP} \quad=\mathrm{C}$-reactive protein

GP Ib-IX-V = glycoprotein complex (=GP Ib $\alpha$, GP Ib $\beta$, GP IX and GP V), P selectin ligand

ICAM = intercellular adhesion molecule, LFA-1 ligand

IFN- $\alpha \quad=$ interferon-alpha

IL $\quad=$ interleukin

LFA-1 = lymphocyte function-associated antigen-1 (immunoglobulin)

MCP-1 = monocyte chemoattractant protein-1

MMP = matrix metalloproteinase

oxLDL = oxidized low density lipoprotein

PCAM = platelet/endothelial cell adhesion molecule

ROS $\quad=$ reactive oxygen species

sCD40L = soluble CD40 ligand

$\mathrm{TNF}-\alpha=$ tumor necrosis factor-alpha

VCAM = vascular cell adhesion molecule, VLA-4 ligand

VLA-4 = very late antigen-4, integrin 
Tables and Figures

Table 1: Targets of the main pathological processes assessed using specific MR markers and their associated MR protocols.

Figure 1: Adhesion molecules and ligands involved in the initial phases of vascular inflammation (a), and cell responses in the vessel wall during inflammation and plaque formation (b). The initial inflammation cascade is shown with monocyte activation and secretion of TNF- $\alpha$ and IL1, followed by pathways involving monocytes, T-lymphocytes, endothelial cells and platelets (a). Endothelial cells are then activated and favor adherence of activated platelets and leukocytes (b). Smooth muscle cells are also activated and changed their phenotype. Plaque formation is also characterized by the presence of oxidized lipids, monocyte migration and homing of macrophages, with the final interrelationship between inflammation and thrombosis (b).

Figure 2: Establishing a new standard for plaque characterization, from histology to MRI (ex vivo imaging) (ex-vivo MRI of a calcified lesion in a Watanabe rabbit). Top row: standard HES histology and Von Kossa staining for calcification. Bottom row: Ex-vivo multi-contrast MR images (T1 and T2 spin echo). No signal for calcified tissue is seen with either sequence (adapted from Chaabane et al., Magn Reson Mater Phy, 2000) ${ }^{116}$.

Figure 3: Dynamic contrast enhancement in the abdominal ApoE-/- mouse aorta with a macromolecular paramagnetic blood pool agent (from Chaabane et al., Magn Reson Mater Phy, 2004, with permission) ${ }^{55}$

Figure 4: Inflammation imaging with iron oxide particles: susceptibility-induced signal loss in a cholesterol-fed rabbit after denudation and balloon angioplasty of the infra-renal abdominal aorta (adapted from M. Sigovan et al., submitted to Magn Reson Med). Top row: In vivo gradient echo imaging (pre- and post-contrast). Bottom row: Histology with Perls staining shows iron in blue at the shoulder of the lesion. Ex vivo multi-contrast images (from left to right: proton density, gradient echo and $\mathrm{T} 2$ spin echo) show signal loss at the same location. 
Figure 5: Molecular imaging of inflammation in the mouse aortic sinus. Cardiac and respiratory gated MRI before and after injection of iron oxide nanoparticles targeted to the VCAM-1 adhesion molecule. The high specificity of the probe was obtained by grafting a peptide identified by phage display technique (from Nahrendorf et al., Circulation 2006, with permission) ${ }^{91}$. 
Table 1: Targets of the main pathological processes assessed using specific MR markers and their associated MR protocols.

\begin{tabular}{|c|c|c|c|c|}
\hline $\begin{array}{l}\text { Pathological } \\
\text { processes }\end{array}$ & MR markers & Target & MR methodology, species & References \\
\hline $\begin{array}{l}\text { Inflammation } \\
\text { (Angiogenesis) }\end{array}$ & $\begin{array}{l}\text { Gd Chelates } \\
\text { Blood pool agents (Gd liposomes, Gd macromolecules) }\end{array}$ & $\begin{array}{l}\text { Non specific : permeability and leakage } \\
\text { Non specific : permeability and leakage }\end{array}$ & $\begin{array}{l}\text { Clinical, dynamic } \mathrm{Tl} \text {, increased permeability and vascularity } \\
\mathrm{T} 1 \text {, animals (rabbits, mice), increased permeability and vascularity }\end{array}$ & $\begin{array}{l}42,46,50 \\
55,81\end{array}$ \\
\hline \multirow{7}{*}{ Inflammation } & Iron oxide particles (SPIO, USPIO) & Activated macrophages & $\begin{array}{l}\text { Ex-vivo T2*(SPIO) } \\
\text { In-vivo T2*(USPIO), rabbits } \\
\text { Clinical, T2* (aorta, carotids) }\end{array}$ & $\begin{array}{l}71 \\
64,66,68,69,115 \\
65,72-75\end{array}$ \\
\hline & Iron oxide particles (mimetic Ab VLA4+fluorochrome) & Adhesion Molecules & VCAM-1, T1/T2*ex-vivo, in-vivo (mice) & $49,83,91$ \\
\hline & Gd platforms (biomimetic carboxymethyldextran-Gd) & Adhesion molecules & Selectins, $\mathrm{T} 1$, in-vivo (mice) & 92 \\
\hline & $\begin{array}{l}\text { Gd platforms (perfluorocarbon emulsion+ } \\
\text { peptidomimetic vibronectin antagonist=RGD) }\end{array}$ & Integrins $(\alpha v \beta 3)$ & In vivo Rabbit aorta(fat diet), $\mathrm{T} 1$ & 89,90 \\
\hline & Gd micelles & Macrophage scavanger receptor & Mice & 98,117 \\
\hline & Theranostics nanoparticles (multifunctional USPIO) & Macrophages & Mice & 118 \\
\hline & In vitro labeling (iron particles, Indium111) & Monocytes/Macrophages & Mice & $80,119,120$ \\
\hline \multirow{4}{*}{ Oxydative stress } & LDL labelled (Gd chelates + Fluorochrome) & Lipid distribution & In vitro LDL labelling & 95 \\
\hline & $\begin{array}{l}\text { Lipophilic Gd chelates, HDL or Lipid-based Gd } \\
\text { nanoparticles }\end{array}$ & Lipid distribution & Gadofluorine, micelles or liposomes, rabbit aorta, $\mathrm{T} 1$ & $81,82,96,97$ \\
\hline & Functionalized Gd chelate & MMP's & In vivo $\mathrm{T} 1$, mice & 99,121 \\
\hline & Serotonin Gd chelate (SMART) & Myeloperoxidase & T1 upon enzyme activation, in vitro & 100 \\
\hline \multirow[b]{2}{*}{ Proliferation } & \multirow[t]{2}{*}{ Gd platforms (perfluorocarbon emulsion+ Biotin) } & SMC & In vitro, cultured SMC, 19F imaging & 101 \\
\hline & & Tissue Factor (via TF-Ab-avidin) & $\mathrm{T} 1 / \mathrm{T} 2$ relaxivities $(=\mathrm{f}(\mathrm{B} 0))$ & 56 \\
\hline \multirow{4}{*}{ Angiogenesis } & Iron oxide particles (mimetic Ab VLA4+fluorochrome) & Activated Endothelial cells & In vivo, ApoE mice, T2 & 49,91 \\
\hline & Iron oxide particles (CD62E Ab fragmant ) & E selectin & Culture cells & 84 \\
\hline & Functionnalized Gd complexes & E selectin & Culture cells, mice (brain) & 85,87 \\
\hline & $\begin{array}{l}\text { Gd platforms (perfluorocarbon emulsion+ } \\
\text { peptidomimetic vibronectiin antagonist) }\end{array}$ & Integrins ( $\alpha v \beta 3)$, & $\begin{array}{l}\text { In vivo Rabbit aorta(fat diet), } \mathrm{T} 1 \\
\text { In vivo Rabbit aorta(+drug), } \mathrm{T} 1\end{array}$ & $\begin{array}{l}89 \\
88\end{array}$ \\
\hline & Iron oxide particles (CLIO-Annexin v+Cy55) & Annexin V & Cells expressing phosphatidylserine, mice, $\mathrm{T} 2$ & 102 \\
\hline Apoptosis & Lipid-based Gd or Fe (+quantum dots) & Annexin V & Cells expressing phosphatidylserine, $\mathrm{T} 1 / \mathrm{T} 2$ & 103,104 \\
\hline \multirow[t]{2}{*}{ Thrombogenesis } & No contrast agents (natural iron derivatives) & Thrombus & Specific MR sequences & $33,34,105$ \\
\hline & Functionnalized Gd complexes (EP-, EPIX) & Fibrin & Fibrin, T1 sequences, in vivo (rabbits, swine) & $106-108$ \\
\hline Thrombogenesis & Gd platforms ((perfluorocarbon emulsion+ Biotin) & Fibrin & Fibrin (via Fibrin-Ab-avidin), $\mathrm{T} 1$ and 19F & $109,110,122$ \\
\hline
\end{tabular}


Figure 1: Adhesion molecules and ligands involved in the initial phases of vascular inflammation (a), and cell responses in the vessel wall during inflammation and plaque formation (b). The initial inflammation cascade is shown with monocyte activation and secretion of TNF- $\alpha$ and IL1, followed by pathways involving monocytes, T-lymphocytes, endothelial cells and platelets (a). Endothelial cells are then activated and favor adherence of activated platelets and leukocytes (b). Smooth muscle cells are also activated and changed their phenotype. Plaque formation is also characterized by the presence of oxidized lipids, monocyte migration and homing of macrophages, with the final interrelationship between inflammation and thrombosis (b).
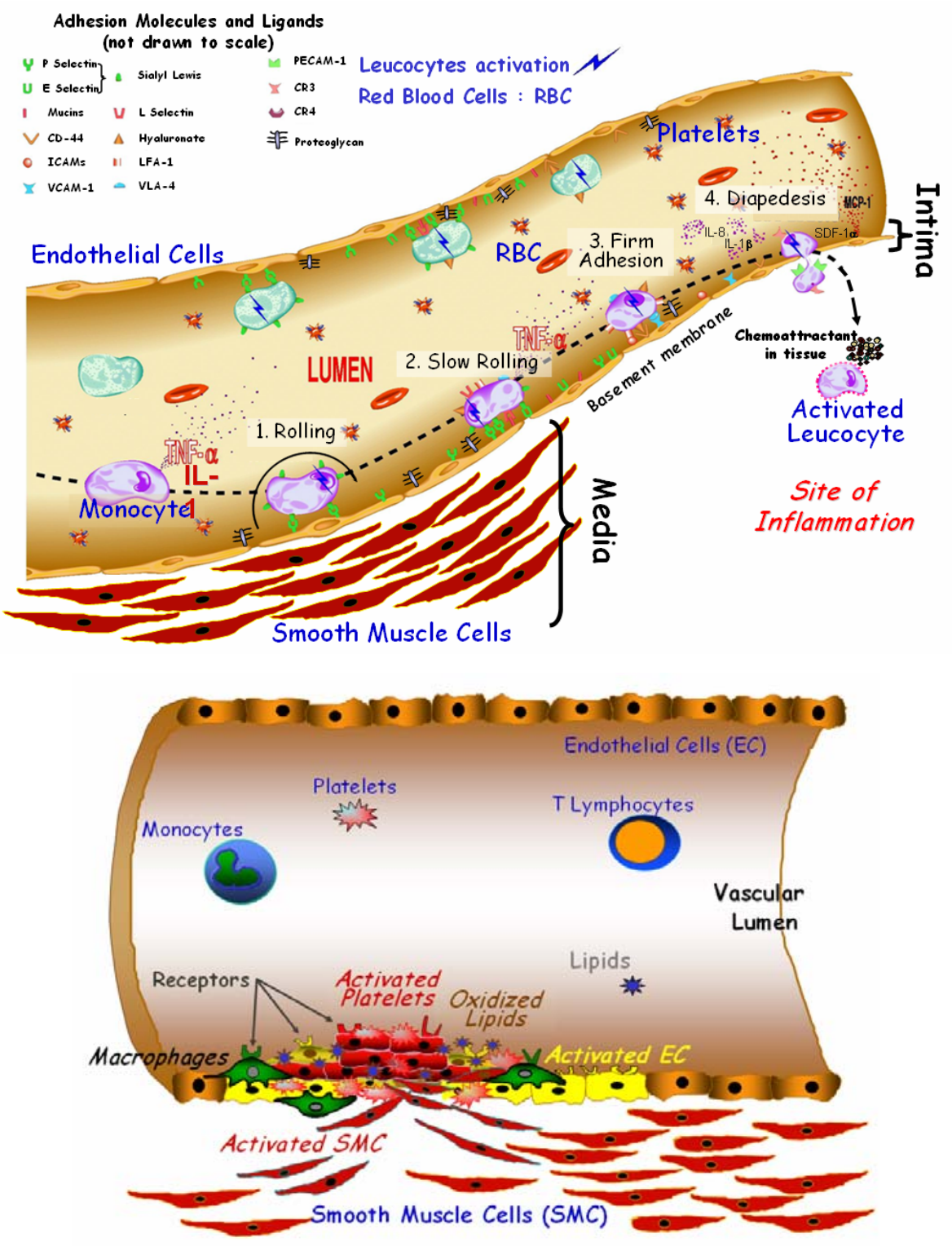
Figure 2: Establishing a new standard for plaque characterization, from histology to MRI (ex vivo imaging) (ex-vivo MRI of a calcified lesion in a Watanabe rabbit). Top row: standard HES histology and Von Kossa staining for calcification. Bottom row: Ex-vivo multi-contrast MR images (T1 and T2 spin echo). No signal for calcified tissue is seen with either sequence (adapted from Chaabane et al., Magn Reson Mater Phy, 2000) ${ }^{116}$.

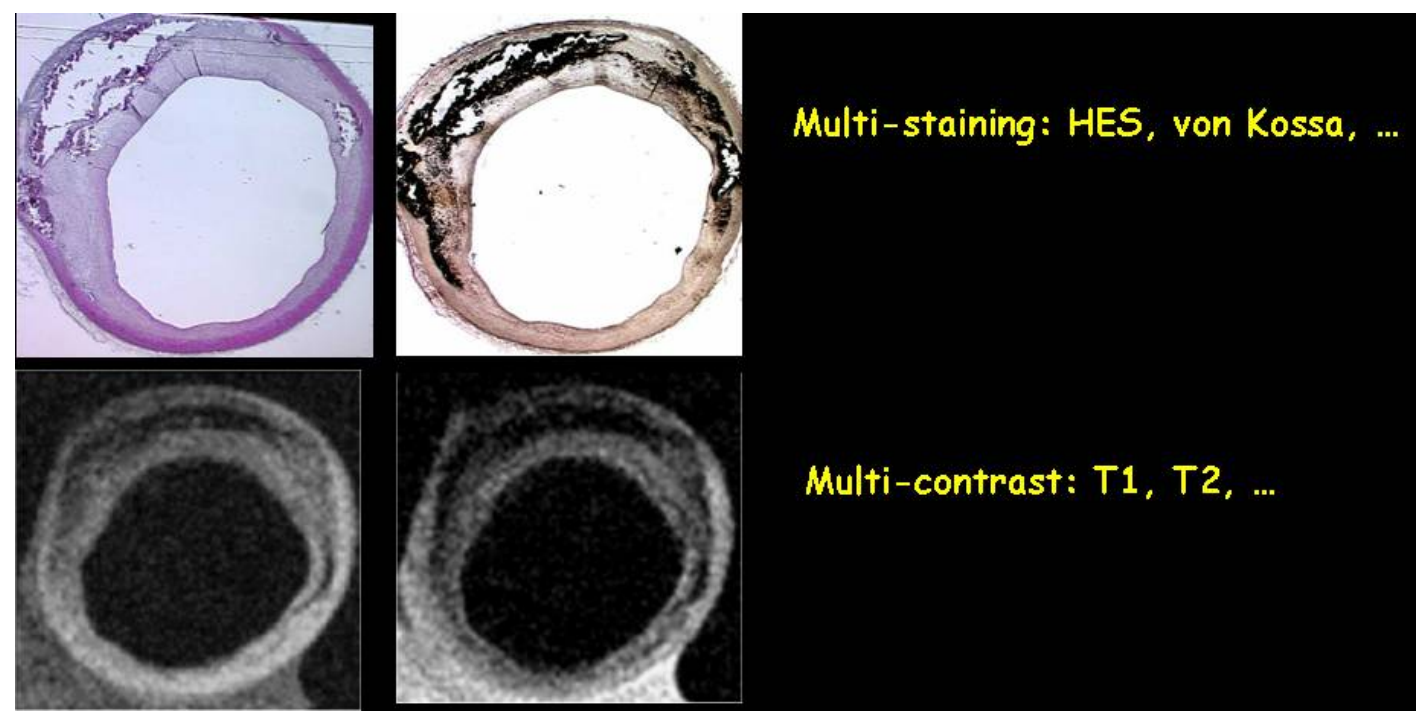


Figure 3: Dynamic contrast enhancement in the abdominal ApoE-/- mouse aorta with a macromolecular paramagnetic blood pool agent (from Chaabane et al., Magn Reson Mater Phy, 2004, with permission) ${ }^{55}$

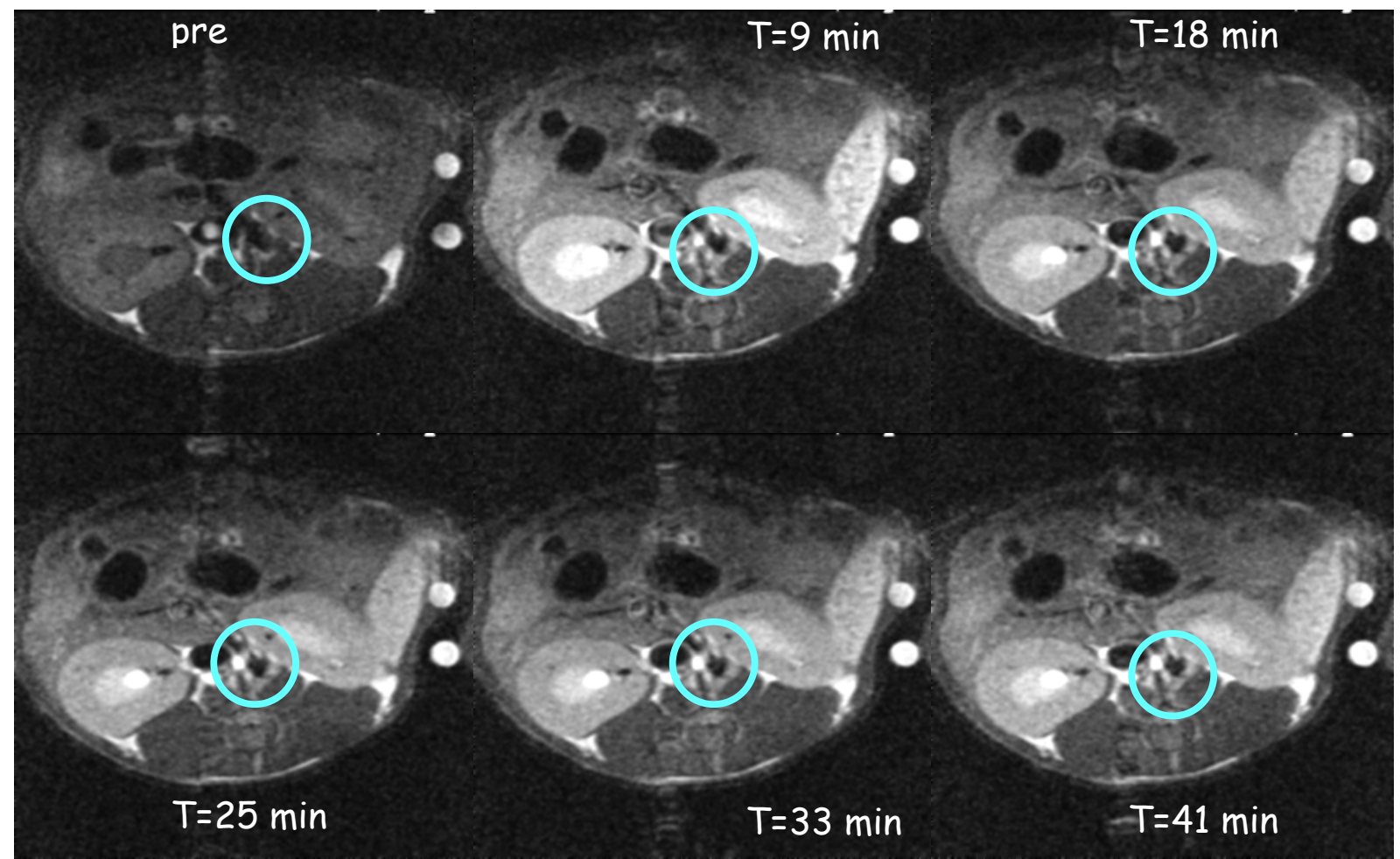


Figure 4: Inflammation imaging with iron oxide particles: susceptibility-induced signal loss in a cholesterol-fed rabbit after denudation and balloon angioplasty of the infra-renal abdominal aorta (adapted from M. Sigovan et al., submitted to Magn Reson Med). Top row: In vivo gradient echo imaging (pre- and post-contrast). Bottom row: Histology with Perls staining shows iron in blue at the shoulder of the lesion. Ex vivo multi-contrast images (from left to right: proton density, gradient echo and T2 spin echo) show signal loss at the same location.

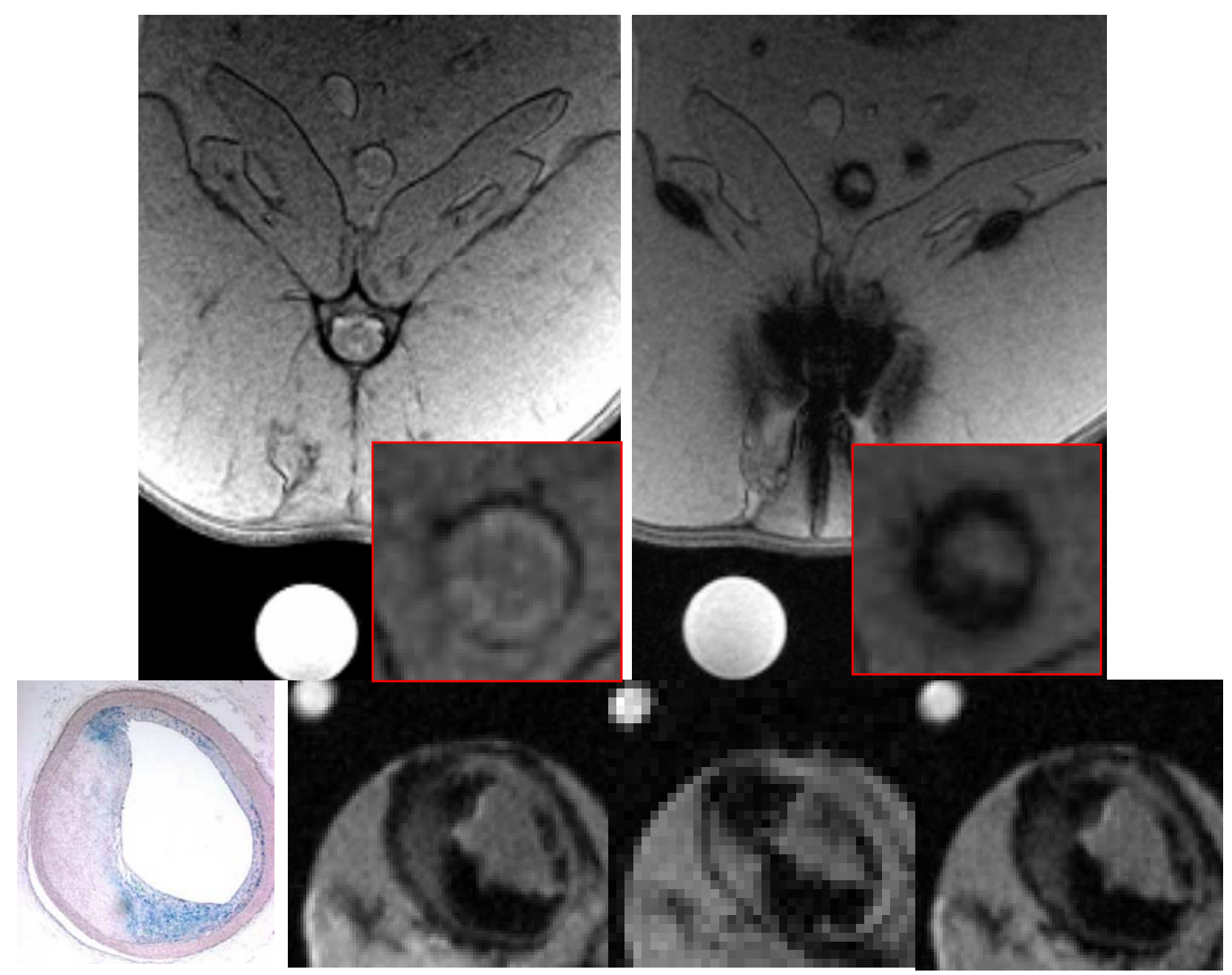


Figure 5: Molecular imaging of inflammation in the mouse aortic sinus. Cardiac and respiratory gated MRI before and after injection of iron oxide nanoparticles targeted to the VCAM-1 adhesion molecule. The high specificity of the probe was obtained by grafting a peptide identified by phage display technique (from Nahrendorf et al., Circulation 2006, with permission) ${ }^{91}$.

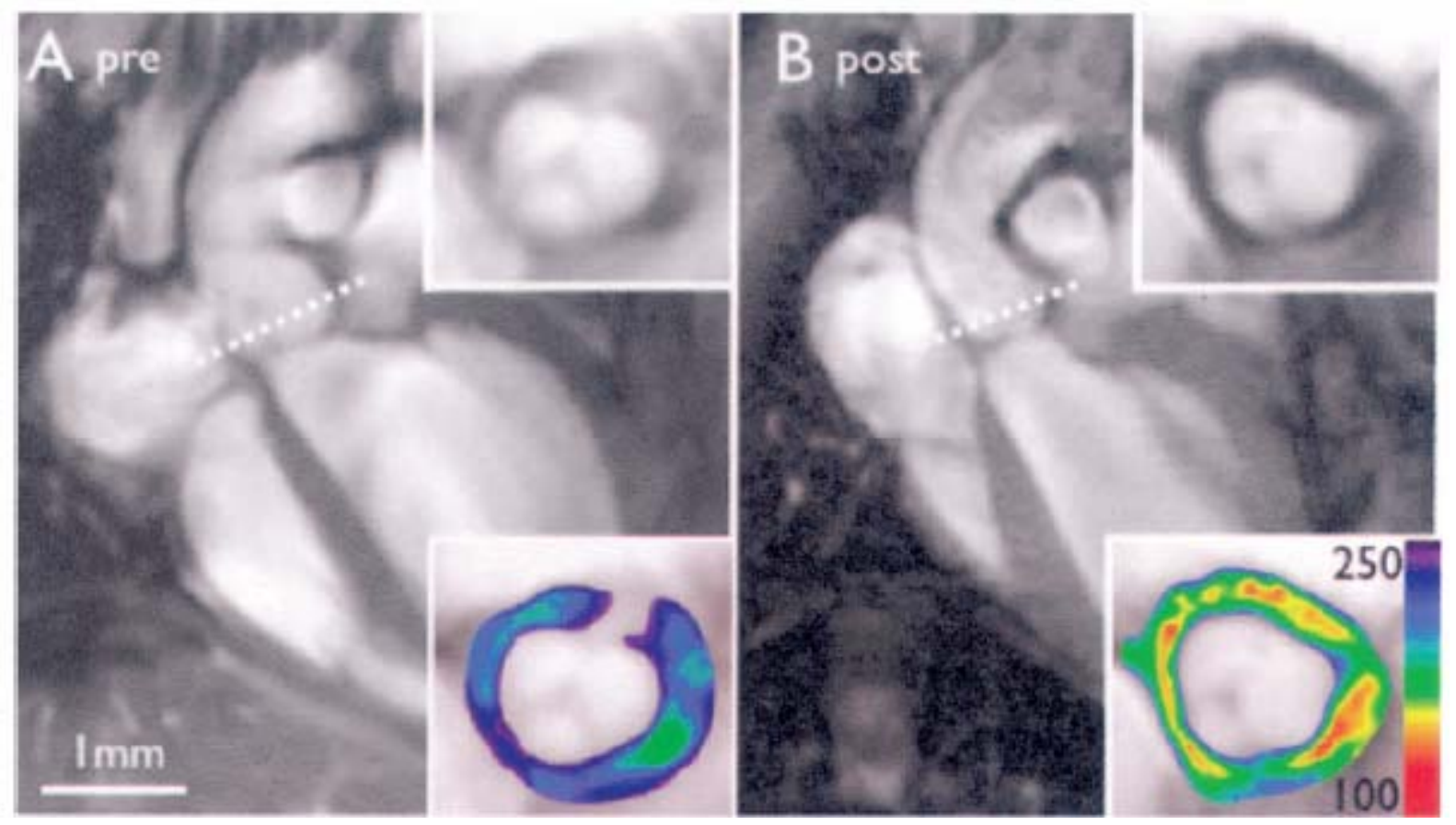

